\title{
Foreword \\ Brexit, the Courts of Justice of the EU and epignosis: a constitutional guide
}

\section{Dora Kostakopoulou}

In the domain of politics, trial and error are frequent occurrences. Through trial and error we tend to discover that political decisions, policy choices and even customary ways of doing things are no longer sustainable and thus in need of revision. The need for revision is accentuated when decisions and policies harm actual persons. In such cases, justice entails not only a duty not to harm human beings but also a duty to recognise the harmful impact of decisions and policies on persons' rights and legitimate interests. There is nothing wrong in admitting mistakes or misjudgements and changing course. The doors of perception are not always fully open for human beings; information asymmetries, errors of judgement, ideological standpoints and self-interest often lead individuals to poor visualisations of the future and thus to imprudent actions.

What is wrong, and often inexcusable, is to refuse to learn from error and to let it become irreparably destructive. In political life, inertia or the suppression of new information or a simple refusal to admit error in an attempt to save face and to maintain the illusionary hope that things might just work out in the end become manifestations of poor judgement and thus of very poor and ineffective leadership.

Both Advocate-General Campos Sanchez-Bordona, who delivered his opinion on the revocability of Article 50 TEU on 4 December 2018, ${ }^{1}$ and the Court of Justice of the EU, which agreed with his interpretation that the UK can revoke the notification of its intention to withdraw from the EU on Monday, 10 December 2018 unilaterally, ${ }^{2}$ essentially confirmed that trial and error are common in politics and that countries, like individuals, are entitled to change their mind.

1 Case C-621/18, Wightman and Others $v$ Secretary of State for Exiting the European Union, Opinion delivered on 4 December 2018, Luxembourg. The full text is available on the CURIA website.

2 Case C-621/18, Judgment of 10 December 2018. The full text is available on the CURIA website. 
Delivering the judgment a day before the scheduled crucial vote on the Withdrawal Agreement in the House of Commons, which was postponed by the Prime Minister, the Court of Justice suddenly opened the door for an epignosis and the possible abandonment of 'cul-de-sacs' and 'enigma variations', that is, a no-deal Brexit, an EEA model of EU membership, a 'Norway plus' model and so on, in the UK's relationship with the EU.

Turning points like this do not happen frequently. Quite often, an epignosis takes place in retrospect; that is, when we experience what we have done and realise that what happened was different from what we had expected or had planned or simply had wished for. In other words, turning points occur when the consequences of decisions or actions are felt and reflected upon. In such cases, individuals could then engage in damage limitation.

Being granted the authorisation of the unilateral revocation of the notification to withdraw from the EU until such time as the withdrawal agreement is formally concluded in accordance with domestic constitutional requirements is a gift and a game changer. The Advocate-General viewed it as manifestation of state sovereignty in the light of the Vienna Convention on the Law of Treaties and an expression of the principle of respect for national identities enshrined in Article 4 TEU. The Court of Justice of the EU agreed that Article 50 TEU is a voluntary exit clause for its Member States and not an expulsion device.

As the Court put it:

the revocation by a Member State of the notification of its intention to withdraw, before the occurrence of one of the events referred to in paragraph 57 of the present judgment, reflects a sovereign decision by that State to retain its status as a Member State of the European Union, a status which is not suspended or altered by that notification. ${ }^{3}$

And 'given that a State cannot be forced to accede to the European Union against its will, neither can it be forced to withdraw from the European Union against its will'. ${ }^{4}$

Ibid., para 59.

4 Ibid., para 65. In addressing the argument that the notification of the revocation cannot be unilateral, the Court stated (at para. 72) that:

as regards the proposal of the Council and the Commission that the right of the Member State concerned to revoke the notification of its intention to withdraw should be subject to the unanimous approval of the European Council, that requirement would transform a unilateral sovereign right into a conditional right subject to an approval procedure. Such an approval procedure would be incompatible with the principle, referred to in paragraphs 65,67 and 69 of the present judgment, that a Member State cannot be forced to leave the European Union against its will. 


\section{Accordingly:}

Article 50 TEU must be interpreted as meaning that, where a Member State has notified the European Council, in accordance with that article, of its intention to withdraw from the EU, that article allows that Member State - for as long as a withdrawal agreement concluded between that Member State and the EU has not entered into force or, if no such agreement has been concluded, for as long as the two-year period laid down in Article 50(3) TEU, possibly extended in accordance with that paragraph, has not expired - to revoke that notification unilaterally, in an unequivocal and unconditional manner, by a notice addressed to the European Council in writing, after the Member State concerned has taken the revocation decision in accordance with its constitutional requirements. The purpose of that revocation is to confirm the EU membership of the Member State concerned under terms that are unchanged as regards its status as a Member State, and that revocation brings the withdrawal procedure to an end. ${ }^{5}$

Academics and legal experts had supported the revocability of Article 50 in the past. Jean-Claude Piris had stated in The Financial Times 'intentions can change' ${ }^{6}$ while Paul Craig had commented that a Member State could not be forced to withdraw from the EU if it changed its mind. ${ }^{7}$

In 2015/2016 political elites in the UK were over-optimistic about a future outside the European Union. They almost fictionalised it. They sought to convince the electorate by campaigning for an independent trade policy and telling people how the UK would prosper from trade deals with the US, Canada, Australia, India, China, New Zealand and other countries. At the time of the referendum on the UK's continued membership of the EU in June 2016, nationalism and the 'taking back control' agenda had aroused strong passions in the collective soul and had narrowed both human empathy and critical reasoning. A rise in racism, xenophobia, hate crime and divisions in society ensued. As 2018 draws to its close, pragmatism, which has traditionally characterised British politics and policy, gradually, albeit slowly, returns. It has become increasingly clear that the country would be poorer and less competitive outside the EU; higher inflation, lower GDP per capita, a rise in unemployment and falling house prices are inevitable according to most economists. People's incomes and jobs are at stake and the flight of businesses to other Member States confirms this. The idea of a 'global Britain' is acknowledged to be a paradox given that the country is negotiating its exit from the regional partnership and is turning away from the world it helped create with the other Member States since 1973, including all the trade agreements the EU

\section{Ibid., para 75.}

6 'Article 50 is not for ever and the UK could change its mind', The Financial Times, 1/09/2016.

7 'Brexit: A Drama in Six Acts' (2016) European Law Review 447, p. 464. 
has concluded with many third countries around the world. A global Britain cannot be built on a policy of undoing togetherness. The invocation of 'the spirit of the nation' or 'the will of the people' becomes progressively entangled with notions such as authored destructiveness or a collective suicide.

There are other dimensions too. One has to recognise that the unrestrained operation of the principle of majority rule tends to subvert, and not to advance, democratic political processes. After all, constitutions are drawn in order to protect individuals and groups from unrestrained electoral majoritarianism. Safeguarding the rights of the individual is an important dimension of democracy: "no society can be considered truly democratic if its citizens are denied the possibility of vindicating their legal rights in judicial proceedings, whether against the oppressive acts of a powerful legislature - even a democratically elected one - or against the unlawful practices of an overweening administration' ${ }^{8}$ And while liberal democracies in the main promote and safeguard fundamental rights, other types of democracy can easily undermine them and restrict them. In the latter case, the majoritarian democracy framework is used in order to promote institutional unsettlement and renegotiation and eventually to legitimise either a narrower interpretation of rights or their erosion. Accordingly, majoritarian democracy is used to undermine constitutional democracy and liberal values.

Certainly, when a 'pro-Leave' majoritarian decision, such as the outcome of the UK's referendum on 23 June 2016, results in depriving millions of people of their rights thereby effectively undermining their life worlds and the future of their families, then there is no reason for thinking that such a decision complies with the values and the rights-affirming nature of constitutional democracy. It is also highly debatable whether the domestic electoral cost of aborting Brexit can outweigh the political costs of damaging democratic constitutionalism and cancelling rights which sustain life-worlds and social worlds for millions of people. Nor can it compensate for the unnecessary stress inflicted upon millions of individuals, including 1.2 million British nationals living in the EU.

But in every level of human activity and in all realms of politics there is the choice of changing course in the presence of more information, less ideological thinking and countervailing forces. Ideological politics, often reinforced by doctrinal commitments, is prone to de-mythologisation. To fall prey to a continuous cult of unreason and to pretend that the choice of reversing Brexit is unavailable because 'Brexit means Brexit' is an unacceptable error of judgement. If all the plans on the table and expert evidence show that Brexit was a

8 G. Federico Mancini and David T. Keeling, 'Democracy and the European Court of Justice', (1994) 57(2) The Modern Law Review 175-90, at 181. 
game that cannot be won for the benefit of present and future generations in the UK (and in the EU), the revocation of the withdrawing intention is required in the national interest. The Court of Justice's decision on Article 50 TEU on 10 December 2018 favoured flexibility and changeability under public law and signalled that trial and error in politics are normal.

The narratives, assumptions and (false) promises that surrounded the EU referendum campaign in 2016 in the UK and its aftermath cease to matter when there are grounds capable of justifying the reversal of the notification to exit the EU supported by cogent evidence and arguments. There is nothing particularly embarrassing in changing one's mind and/or admitting mood-swings, be they personal or collective. Nor would Britain be a unique case; almost all countries have experienced them. And all countries are free to devise and revise "ends in view' and thus to change courses of action. Motion and change are inherent in the political process.

But even if the UK decides upon the path of Brexit, the echoes of the Court's decision of 10 December 2018 will continue to be a reminder of the kind of governance the UK left behind and of the symbiotic linkages among the EU, the Member States and the EU citizens. In a few, sensational, paragraphs, the highest court in the European Union summarised the raison d'être of the EU and of its normative framework.

As the Court of Justice reasoned:

45. According to settled case-law of the Court, that autonomy of EU law with respect both to the law of the Member States and to international law is justified by the essential characteristics of the European Union and its law, relating in particular to the constitutional structure of the European Union and the very nature of that law. EU law is characterised by the fact that it stems from an independent source of law, namely the Treaties, by its primacy over the laws of the Member States, and by the direct effect of a whole series of provisions which are applicable to their nationals and to the Member States themselves. Those characteristics have given rise to a structured network of principles, rules and mutually interdependent legal relations binding the European Union and its Member States reciprocally as well as binding its Member States to each other (judgment of 6 March 2018, Achmea, C 284/16, EU:C:2018:158, paragraph 33 and the case-law cited).

These statements do not only reflect the essence of European integration thereby eschewing populist depictions of the latter as a capitalist or a purely market integration experiment, but also signal to all the Member States the

9 This is a term used by John Dewey; The Way we Think (Lexington, MA: D.C. Heath, 1910), p. 164. For a discussion on institutional change, see D. Kostakopoulou, Institutional Constructivism in Social Sciences and Law: Frames of Mind, Patterns of Change (Cambridge: Cambridge University Press, 2018), pp. 68-101. 
principles and values they need to respect and defend. The reference to the structured network of principles, rules and mutually interdependent legal relations binding the EU and its Member States reveals the Court's harmonising of national reality worlds: each Member State is not only required to check its actions and policies against the principles and rules of the EU but also against those of the other MS thereby entangling the EU and its MS into a harmonising whole aimed at serving the citizens. In this respect, the Court acts as a wise, unifying voice in a Europe of weakened interconnections and divisions. It reminds national executives across the EU that all have an equal and joint responsibility to maintain the integrity of the 'structured network of principles, rules and interdependent legal relations'.

The UK's decision to withdraw from the Union has not severed the interconnections nor has made the relations between the Member States and the UK meaningless. Counselling European unity and principled mutual coordination among the Member States, the Court proceeded to emphasise the importance of a holistic (at para 46), teleological (at para 47) and contextual (at para 47) perspective in order to address the fact that Article 50 TEU does not explicitly address the subject of revocation. In the absence of an express provision governing revocation of the notification of the intention to withdraw (para 58), that revocation is subject to the rules laid down in Article 50(1) TEU for the withdrawal itself, with the result that it may be decided upon unilaterally, in accordance "with the constitutional requirements of the Member State concerned'. Accordingly, such an action would reflect 'a sovereign decision by that State to retain its status as a Member State of the European Union, a status which is not suspended or altered by that notification' (para 59).

Having made this statement, the Court then proceeded to furnish with admirable clarity the normative presuppositional framework within which its decision on the unilateral revocation of the notification to withdraw from the Union could be situated in just four, but powerful, paragraphs (61-64). This normative presuppositional framework unfolds the main characteristics of EU governance commencing with the remembrance of the past, that is, the enmities and divisions that have characterised Europe.

Accordingly, in paragraph 61, the Court emphasised the aims of the European project, namely, the creation of an ever closer union among the peoples of Europe and the elimination of the barriers that divide Europe (para 61). In opting for regional integration, the drafters of the Treaties made history because they sought a future that did not resemble the troubled past. Since the creation of an ever closer union among the peoples of Europe continues to be the future that must be brought into being, the important guideposts chosen by the Court were: (i) the values underpinning the EU and the importance of the Charter of Fundamental Rights, (ii) the need for a real and effective commitment to those values (para 63) and (iii) the fundamental status of Union 
citizenship which requires safeguarding the rights of all Union citizens. By using the word 'all', the Court included millions of UK nationals who have not exercised their free movement rights and who will lose their EU citizenship status, if Brexit takes place.

This is an admirable affirmation of the ties that bind the EU Member States in a union and of what the important indicators of the European Union reality are.

As the Court stated:

62. It is also appropriate to underline the importance of the values of liberty and democracy, referred to in the second and fourth recitals of the preamble to the TEU, which are among the common values referred to in Article 2 of that Treaty and in the preamble to the Charter of Fundamental Rights of the European Union, and which thus form part of the very foundations of the European Union legal order (see, to that effect, judgment of 3 September 2008, Kadi and Al Barakaat International Foundation v Council and Commission, C 402/05 P and C 415/05 P, EU:C:2008:461, paras 303 and 304).

63. As is apparent from Article 49 TEU, which provides the possibility for any European State to apply to become a member of the European Union and to which Article 50 TEU, on the right of withdrawal, is the counterpart, the European Union is composed of States which have freely and voluntarily committed themselves to those values, and EU law is thus based on the fundamental premiss that each Member State shares with all the other Member States, and recognises that those Member States share with it, those same values (see, to that effect, judgment of 25 July 2018, Minister for Justice and Equality (Deficiencies in the system of justice), C 216/18 PPU, EU:C:2018:586, paragraph 35).

64. It must also be noted that, since citizenship of the Union is intended to be the fundamental status of nationals of the Member States (see, to that effect, judgments of 20 September 2001, Grzelczyk, C 184/99, EU:C:2001:458, paragraph 31; of 19 October 2004, Zhu and Chen, C 200/02, EU:C:2004:639, paragraph 25; and of 2 March 2010, Rottmann, C 135/08, EU:C:2010:104, paragraph 43), any withdrawal of a Member State from the European Union is liable to have a considerable impact on the rights of all Union citizens, including, inter alia, their right to free movement, as regards both nationals of the Member State concerned and nationals of other Member States.

By affirming the interplay of the political objective of the transcendence of divisions in Europe (para 61), the values of freedom and democracy and the Charter (para 62), the Member States' free and voluntary commitment to the values espoused by the EU and its partners (para 63) and the fundamental status of EU citizenship (para 64), the Court unravelled the constitutional bedrock of 'togetherness in the European Union' and the 'burden of membership'.

The EU constitution is not akin to a particular belief system that is subject to situational changes depending on country specific contexts, countries' images of themselves, national ideologies or electoral currents. It stands above all the above factors because what really matters for EU governance is peaceful 
human living within a structured network of principles, rules and mutually interdependent relations. For this to happen, compliance on the part of the Member States, and their peoples' adherence, to the grand normative framework are required. Here the Court intimated the need for consistency as far as Poland and Hungary are concerned and hoped for the UK to change its mind.

It was aware of the fact that one way of reducing conflict or tensions among conflicting reality worlds is to show that parties share more things in common than they actually think and, however discrepant the positions might appear to be, there is, or must be, an underlying commitment to shared programmatic principles. The Court thus took upon itself to reaffirm the common EU institutional reality thereby pointing out directions of thought and action that would strengthen socio-political relations in the EU. It saw European destiny as 'a kind of melody in which each note takes on its musical meaning when it is placed in its proper position among all the others'. ${ }^{10}$

But if political elites in the UK continue to deny the European world Britain has helped to construct over the decades and there is no revocation of the withdrawal notification, the EU cannot but continue its unifying melody. Brexit has been a considerable distraction for the $\mathrm{EU}$ and its multifarious costs must now be mitigated. There is no time, no gain and no advantage from slowing down the process of European integration in order to accommodate the British grievances and demands which have displayed a mercurial shape shifting for a considerable period of time. There are pressing issues and important challenges facing the EU which must be met with confidence, a fully functioning acquis communautaire as well as new ideas and innovative thinking. The Brexit story has subverted the integration dynamic for more than two years and therefore European states, regions, citizens and groups need solidarity enhancing and integration promoting narratives in order to face the future with optimism.

The political usefulness of such narratives is not confined to the fact that they focus peoples' attention and inspire action. They are also important for undermining structures of power and revealing who actually benefits from the weakening of the European project and/or from populist retro-nationalist discourses. Collective fantasies or illusions cannot be dismissed as simple accidental occurrences; they are the by product (ill-thought) of political programmes seeking to manipulate minds and hearts. There is nothing accidental when elites invoke or call upon the essential character of the people in order to scapegoat and harm all those 'others' who deemed to prevent the full realisation of the people. Bad intentions and specific actions and discourses of political parties and groups spreading racism, hatred and xenophobia are no mistakes. They are used by certain forces, namely, undemocratic forces and

\footnotetext{
10 Ortega de Gasset, Man and Crisis (Norwich: Jarrold and Sons, 1959) at p. 122.
} 
power-obsessed political elites seeking to find sources of legitimacy at times when their legitimacy is weak. Populist nationalist narratives also serve certain political ends. But by seeking to conjure up a dependable state of affairs, which in the main requires more concentration of power and more control by the ruling elites, they actually lead to faulty thinking and to a false sense of security.

European integration rose from resistance to unnecessary human suffering and protests against power politics, state totalitarianism and authoritarianism which had led to senseless and devastating wars. Over the decades, it has demonstrated that another world in Europe is possible and beneficial as well as the importance of cherishing democracy, freedom, non-discrimination, rights and peace. Post-Brexit, the EU does not need to embark upon a rebalancing of its priorities. Nor does it need to refine its objectives. It simply needs to continue its principled opposition to power politics and state authoritarianism with vigour and to safeguard the integrity of its political values, the rule of law and respect for human personality and life. These form the source of its political and normative authority. 